\title{
Microbial Screening for Bio-delipidation System of Pre-treated Poultry Slaughterhouse Wastewater: Impact of Solvents, Metal Ions and Detergents on Lipase Activity
}

\author{
S. Mbulawa, S.K.O. Ntwampe, M. Basitere, Y. Mpentshu, C. Dlangamandla and B.S. Chidi
}

\begin{abstract}
This study reports on the microbial screening for a bio-delipidation system of lipid-rich slaughterhouse wastewater, and on the optimal conditions for lipase production and activity. In this study, swaps were collected from the poultry slaughterhouse discharge point for screening, isolation and characterisation of lipolytic microorganisms using molecular techniques. Bacillus cereus strains $A B 1(B F 3)$ and $C C$-1 (B3O) were identified using 16S rRNA techniques. Maximal lipase production for both strains was observed between $\mathrm{pH} 6-8$ and $45-60{ }^{\circ} \mathrm{C}$. Optimal lipase activity for $B F 3$ and $B 30$ was achieved at $\mathrm{pH} 8$ and $60{ }^{\circ} \mathrm{C}$, and at pH 8.83 and $45^{\circ} \mathrm{C}$, respectively. After partial purification, increased activity was observed for $B F 3$ and $B 30$ strains. Solvents, metal ions and detergents (triclosan and trichlorocarbonilide) affected lipase activity. It was concluded that $B F 3$ and $B 30$ strains were suitable candidates for bio-delipidation systems.
\end{abstract}

Keywords - Bio-delipidation, Poultry slaughterhouse wastewater, Lipase activity

Manuscript received September 2018. The authors would like to acknowledge the department of Higher Education and Training (DHET) subsidy allocated funding to Cape Peninsula University of Technology (RK45).

S. Mbulawa is with the Bioresource Engineering Research Group (BioERG), Faculty of Applied Science, Department of Biotehnology Cape Peninsula University of Technology, P.O. Box 652, Cape Town 8000, South Africa.

S. K.O. Ntwampe is the founder of Bioresource Engineering Research Group (BioERG), Faculty of Applied Science, Department of Biotehnology Cape Peninsula University of Technology, P.O. Box 652, Cape Town 8000, South Africa.

M. Basitere is with the Bioresource Engineering Research Group (BioERG), Faculty of Applied Science, Department of Biotehnology Cape Peninsula University of Technology, P.O. Box 652, Cape Town 8000, South Africa.

Y. Mpentshu is with the Bioresource Engineering Research Group (BioERG), Faculty of Applied Science, Department of Biotehnology Cape Peninsula University of Technology, P.O. Box 652, Cape Town 8000, South Africa.

C. Dlangsmsndla is with the Bioresource Engineering Research Group (BioERG), Faculty of Applied Science, Department of Biotehnology Cape Peninsula University of Technology, P.O. Box 652, Cape Town 8000, South Africa.

B.S. Chidi is with the Bioresource Engineering Research Group (BioERG), Faculty of Applied Science, Department of Biotehnology Cape Peninsula University of Technology, P.O. Box 652, Cape Town 8000, South Africa, and Agricultural Research Council (Infruitec-Nietvoorbj), Post-Harvest and Agro-Processing Technologies, Private Bag X5026, Stellenbosch 7599, South Africa.

\section{INTRODUCTION}

Compared to plants and animals, bacterial lipases are the most significant biocatalytic agents for numerous industrial applications [1]. In addition, microbial sourced lipases have also been considered important for biotechnological industrial applications due to their ability to catalyse reactions both in aqueous and non-aqueous systems. Generally, various microorganisms including those from microbial genera Pseudomonas, Bacillus, Staphylococcus, Streptomyces, Penicillium, Aspergillus and Rhizopus [2], commercially produce lipase. These enzymes can be produced by submerged fermentation (SMF) and solid-state fermentation (SSF) on an industrial scale whereby solid substrates such as agro-waste and oils are used as inducers or substrates for lipase production.

Like many other microbially produced extracellular protein, lipase production is also influenced by factors such as, media composition and physicochemical factors, i.e. carbon source, $\mathrm{pH}$ and temperature [3]. In most instances, the lipase production is induced by the presence of lipids, oils and triacylglycerols [4]. However, optimisation of the production conditions is also essential for process perfomance and production costs [5]. Furthermore, the applications of thermo- and alkaline-stable lipases in the bio-delipidation systems is critical due to the extreme/harsh nature of the process conditions [6]. As a result, the optimisation of fermentation conditions and enzyme activity is prioritised to assess the effect of these conditions on enzyme functionality in an environment in which the enzymes will be applied.

Some of the pollutants in poultry slaughterhouse wastewater (PSW) are heavy metals, solvents, and pharmaceuticals including antibiotics and detergents [7]. Their presence in PSW has been established, and they are known to be detrimental to human and environmental health [7]. Hence, the effect of these pollutants on the functionality and stability of the enzymes was investigated in the current study. The aim of this study was therefore, to isolate and characterize potential microorganisms from PSW, optimise lipase production and investigate the impact of environmental factors on the lipase activity and stability. 


\section{MAterials AND MethodS}

\section{A. Isolation and Identification of Lipolytic Bacteria}

Sterile swabs were used to collect lipolytic bacteria from PSW and a local poultry slaughterhouse wastewater discharge point in Cape Town, South Africa. Nutrient broth with olive oil was used as an inducer and the cultures were maintained on nutrient agar by a streaking technique subsequent to incubation at $37{ }^{\circ} \mathrm{C}$ for $48 \mathrm{~h}$, with a regular sub-culturing strategy being implemented to obtain pure colonies. Pure cultures with high lipase activity were subjected to identification by morphologically studying each species under a microscope using a gram staining method, followed by further identification using 16S rRNA sequencing techniques. For $16 \mathrm{~S}$ rRNA analyses, samples were sent to Inqaba Biotechnical Industries (Pretoria, South Africa) for sequencing, with the DNA from the isolates being obtained using a ZR Fungal/Bacterial DNA Kit ${ }^{\mathrm{TM}}$ (Zymo Research, USA). The 16S rRNA target region was amplified by DreamTaq ${ }^{\mathrm{TM}}$ DNA polymerase (Thermo Scientific ${ }^{\mathrm{TM}}, \mathrm{SA}$ ) and the primers used were: (forward) $16 \mathrm{~S}-27 \mathrm{~F}$ 5'-AGAGTTTGATCMTGGCTC-3' and (reverse) 16S-1492R 5'-CGGTTACCTTACGACTT-3'. PCR products were gel extracted using a Zymoclean ${ }^{\mathrm{TM}}$ Gel DNA Recovery kit (Zymo Research, USA). This was followed by sequencing in the forward and reverse directions on an ABI PRISM ${ }^{\mathrm{TM}}$ 3500xl Genetic Analyser. Purified sequences were analysed using a CLC Main Workbench 7 and subjected to a Basic Alignment Search Tool (BLAST) to compare the sequence with those available on the NCBI-NIH database (National Centre for Biotechnical Information, n.d.) for identification of the microorganisms.

\section{B. Screening of Lipase Production/Activity on Agar Plates}

Lipase activity of the isolated strains was determined using agar plate screening methods adapted from [8], using tributyrin medium containing (per litre): $2.5 \mathrm{~g}$ peptone from casein, $3 \mathrm{~g}$ yeast extract, and $12 \mathrm{~g}$ nutrient agar. After autoclaving and cooling of the medium to $60^{\circ} \mathrm{C}, 10 \mathrm{~mL}$ of tributyrin was added. A homogeneous mixture was maintained prior to pouring the media into Petri plates. A loopful of each culture was inoculated on the agar plates and incubated at $37^{\circ} \mathrm{C}$ for $48 \mathrm{~h}$. Presence of lipase activity/production was monitored by a clear zone around the colonies. Microorganisms identified to be lipolytic, using the tributyrin medium screening method, were further screened using a Rhodamine B agar plate method. Rhodamine agar plates consisted of the following (per litre): $8 \mathrm{~g}$ peptone, $4 \mathrm{~g}$ yeast extract, $3 \mathrm{~g} \mathrm{NaCl}$, and $20 \mathrm{~g}$ nutrient agar. Rhodamine $\mathrm{B}$ dye (1 $\mathrm{mg} \mathrm{mL}^{-1}$ ) was prepared and filter-sterilised to make a $10 \mathrm{~mL}$ solution. After autoclaving and cooling of the agar medium to $60{ }^{\circ} \mathrm{C}, 30 \mathrm{~mL}$ of olive oil and $10 \mathrm{~mL}$ of the filter sterilised Rhodamine B solution were added. A loopful of each strain was inoculated on the agar plates and incubated at $37^{\circ} \mathrm{C}$ for $48 \mathrm{~h}$. UV irradiation $(350 \mathrm{~nm})$ was used to assess clearing zones.

C. Optimisation of Lipase Production using Response Surface Methodology (RSM)

Response surface methodology was employed to optimise the production of lipases. Design-Expert® software v.6.0.8 (Stat-Ease, Inc, USA) was used for RSM analyses and for reactor parameter optimisation. A set of 13 experiments was used to ascertain optimum conditions for high lipase production by the isolated strains, $B 3 O$ and $B F 3$. Two parameters ( $\mathrm{pH}$ and temperature) were considered for the RSM design to optimize lipase production. $\mathrm{pH}$ (ranging from 3.17 - 8.83) and temperature (ranging from $23.79-66.21^{\circ} \mathrm{C}$ ) conditions were set according to the RSM experimental design, and tested for lipase production and activity. All the experiments were conducted in triplicates.

\section{Lipase Production}

Positive lipase-producing isolates were inoculated in a fermentation medium ( $\mathrm{pH} 7$ ), incubated at $37{ }^{\circ} \mathrm{C}$ for $72 \mathrm{~h}$, and agitated at $121 \mathrm{rpm}$. The fermentation medium comprised $(\mathrm{g} / \mathrm{L})$ : $5.0 \mathrm{~g}$ of peptone, $10 \mathrm{~g}$ yeast extract and $5.0 \mathrm{~g} \mathrm{NaCl}$ supplemented with $10 \mathrm{~mL}$ of filter-sterilized olive oil [8] to induce lipase production. Quantification of bacterial growth was performed by measuring absorbance at $660 \mathrm{~nm}$ using a UV/V is Jenway spectrophotometer, Cole Parmer, USA.

\section{E. Partial Purification}

Culture broth was centrifuged at $7000 \mathrm{rpm}$ at $4{ }^{\circ} \mathrm{C}$ for $25 \mathrm{~min}$. All supernatants were separated from the biomass pellet with the pellet being resuspended in 50mMTris- $\mathrm{HCl}$ buffer ( $\mathrm{pH} 8.0)$ by vortexing. In order to harvest intracellular lipases, a sonicator was used for the disruption of the cells constituting the pellet for $10 \mathrm{~min}$ at $10 \mathrm{~s}$ intervals to minimise overheating, with sonicated samples being put on ice $\left(4{ }^{\circ} \mathrm{C}\right)$ between sonication cycles. The mixture from the sonicator was centrifuged at 15000 $\mathrm{rpm}$ and $4{ }^{\circ} \mathrm{C}$ for $25 \mathrm{~min}$. Crude enzyme extracts in the form of supernatants from the centrifugation and sonication procedures were recovered and stored at $4{ }^{\circ} \mathrm{C}$ prior to enzyme activity quantification in triplicates. The crude enzyme extracts with high enzyme activity were concentrated by loading on to Bio-Rad/Bio-Gel ${ }^{\circledR}$ P-60 size exclusion chromatography columns equilibrated with potassium phosphate buffer $(50 \mathrm{mM}$ $\mathrm{pH}$ 7.0) with the fractions (5 mL) collected and stored at $4{ }^{\circ} \mathrm{C}$ for further use in this study.

\section{F. Determination of Protein Content and Lipase Activity}

Bradford's assay was used to determine the total protein concentrations [9]. Enzyme activity was determined using the lipase assay methods previously used by [10], [11], [12], [13].

\section{G. Effect of $p H$ and Temperature on Enzyme Stability and Activity}

Optimum $\mathrm{pH}$ for lipase (semi purified) stability was determined spectrophotometrically using an adapted method from [8]. 50mM concentrations of citrate buffer ( $\mathrm{pH} 3.0-5.0$ ), Tris- $\mathrm{HCl}$ buffer ( $\mathrm{pH}$ 6.0-7.0), $\mathrm{K}_{2} \mathrm{HPO}_{4}-\mathrm{KH}_{2} \mathrm{PO}_{4}(\mathrm{pH}$ 8.0-9.0) and glycine- $\mathrm{KOH}$ buffer $(\mathrm{pH} 10.0)$ were used for reaction mixtures. A typical assay reaction mixture contained $200 \mu \mathrm{L}$ of the semi-purified enzyme and $1800 \mu \mathrm{L}$ of the buffer and incubation at $37{ }^{\circ} \mathrm{C}$ for $15 \mathrm{~min}$. Optimum temperature for stability was studied at a pre-determined optimum $\mathrm{pH}$ by incubating the assay mixtures at different temperatures, i.e. 25 , $45,55,65$ and $75^{\circ} \mathrm{C}$ in a $50 \mathrm{mM}$ phosphate buffer for $30 \mathrm{~min}$, after which the samples were allowed to cool subsequent to 
enzyme activity determination. In both cases, the enzyme activity was measured as described above.

\section{H. Effect of Solvents, Metal ions and Detergents on Enzyme Stability and Activity}

The effect of solvents on enzyme stability was investigated using isopropanol, 2-mercaptoethanol, acetone, methanol, ethanol, hexane, chloroform and toluene. The impact of metal ions on the lipase activity was also studied by similarly incubating the enzymes in the presence of metal salts, i.e. $\mathrm{CaCl}_{2}$, $\mathrm{KCl}, \mathrm{NaCl}_{2}, \mathrm{MgSO}_{4}$, and $\mathrm{Fe}_{2}(\mathrm{SO} 4)_{3}$. Triclosan (TCS) (5 chloro - 2 - (2, 4 - dichlorophenoxy) - phenol), EDTA, and trichlorocarbanilide (3, 4, 4 - trichlorocarbanilide) (TCC) were used for assessing the role of these detergents prior enzyme activity determination. Prior to enzyme activity determination, the reaction mixture of each solvents / metal ions / detergents $(1.8 \mathrm{~mL})$ and crude enzyme $(0.2 \mathrm{~mL})$ were incubated at $37{ }^{\circ} \mathrm{C}$ for $30 \mathrm{~min}$. For comparative analysis, a reference experiment without the solvents, metal ions, detergents was also used.

\section{RESULTS AND DisCUSSION}

\section{A. Plate Assays: Microbial Screening and Lipase Production}

Pure culture samples obtained from poultry slaughterhouse wastewater (PSW), and from a discharge point at a local poultry slaughterhouse,were screened to isolate lipolytic strains using qualitative assay methods. Isolates $(n=20)$ were maintained on nutrient agar, following lipase activity screening procedures on agar plates supplemented with tributyrin. A number $(n=2)$ of isolates produced distinct zones of hydrolysis (clearance) as shown in Figure 1-a2 for strain BF3 and Figure 1-b2 for strain B30. The clearing of zones on tributyrin agar plate was attributed to tributyrin hydrolysis and esterases enzyme activity [14].

The lipase activity was observed in Tween 80 agar plates for $B F 3$ (Fig. 1-a3) and B30 strain (Fig. 1-b3), thus confirming the potential applicability of the isolates in bio-delipidation systems. Additionally, the esterification of free fatty acids and long chain alcohols was confirmed when BF3 (Fig. 1-a4) and B30 strains (Fig. 1-b4) were tested using the Rhodamine B dye assay method. Although, the current study successfully screened for lipase producing isolates using plate assays, very few other studies managed to achieve similar results [15], [8]. The low success rate is a resultant of the insensitivity of the quantitative methods and low enzyme doses on plates, especially when Rhodamine B dye assay is used under UV light.
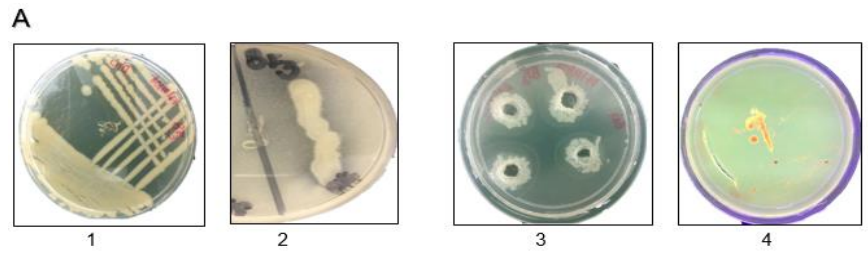

B
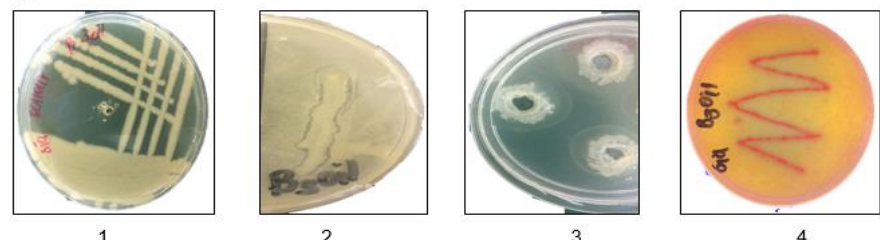

Fig. 1: (a) The screening for lipolytic activity of $B F 3$ on nutrient agar (1); Tributyrin agar plate (2); Tween 80 agar plate (3), Olive oil rhodamine b dye (4). (b) The screening for $B 30$ on nutrient agar (1);

Tributyrin agar plate (2); Tween 80 agar plate (3), Olive oil Rhodamine B dye (4).

\section{B. Isolation and Identification}

Microbial identification of the isolates that showed a high lipolytic potential was achieved by morphological identification and $16 \mathrm{~S}$ rRNA sequencing. The microorganisms were subjected to gram staining for morphological characterisation, with both being gram positive, with a rod shape and a yellow color for $B 3 O$, and while $B F 3$ was coccus. Identification methods using 16S rRNA sequencing confirmed the isolates to be Bacillus cereus, with Genbank accession numbers CP023179.1 (B3O) and MF800922.1 (BF3).

\section{Optimisation of Lipase Production}

Graphical illustrations were generated to study the interactive influence of $\mathrm{pH}$ and temperature on lipase production, while maintaining the production time $(72 \mathrm{~h})$ as an independent parameter. It was crucial to understand these interactions on the semi-purified enzymes because fermentation conditions, environmental, as well as physiological factors are known to impact on lipase production [2]. In different studies, maximum production of lipases by Pseudomonas sp. was achieved between 48 and 96 hours [16], [17], [18]. Maximal lipase production for both strains was achieved between $\mathrm{pH} 6$ and 8, and between at 45 and $60^{\circ} \mathrm{C}$. Maximum lipase activity for Bacillus cereus strain $A B 1$ (BF3) (11.25 $\mathrm{U} \mathrm{mL}^{-1}$ ) (Fig. 2a) and Bacillus cereus CC-1 (B30) (15.50 $\mathrm{U} \mathrm{mL}^{-1}$ ) (Fig. 2b) was obtained under the conditions of $\mathrm{pH} 8$ and $60^{\circ} \mathrm{C}$, and $\mathrm{pH} 8.83$ and $45^{\circ} \mathrm{C}$, respectively. These observations clearly showed the importance of strain variability and the direct role of environmental factors on lipase production. Interestingly, post purification activity for Bacillus cereus strains $A B 1(B F 3)$ and $C C-1$ (B3O) was quantified as 19.47 and $28.36 \mathrm{U} \mathrm{mL}^{-1}$ respectively (data not shown). This improvement in lipase activity highlighted the importance of enzyme purifications for bio-delipidation systems. 


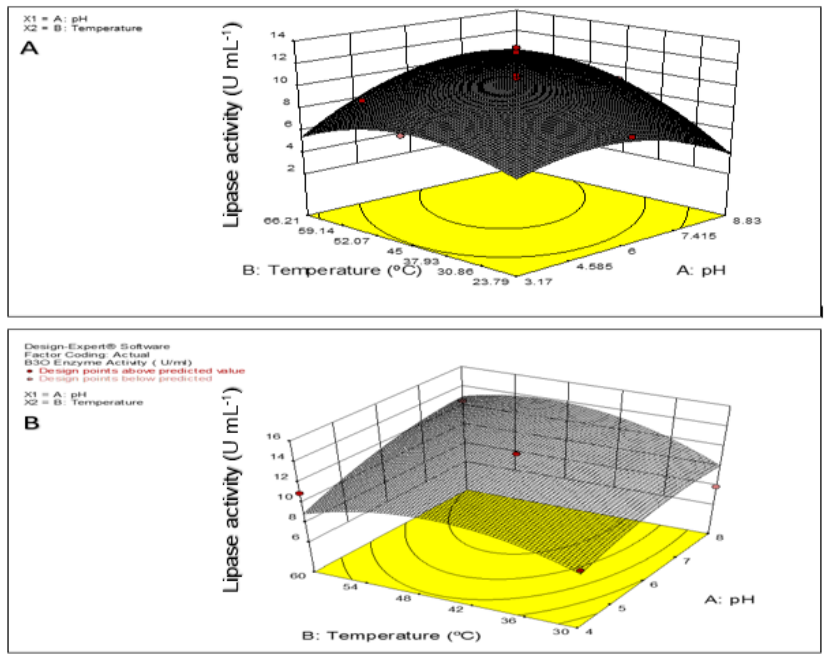

Fig. 2: The interactive role of $\mathrm{pH}$ and temperature on lipase activity of strain $B F 3$ (a) and $B 30(\mathrm{~b})$.

\section{Effect of pH and Temperature on Enzyme Stability and Activity}

As indicated in Fig 3a, the optimal lipase activity for Bacillus cereus (BF3) and Bacillus cereus (B30) was obtained at $\mathrm{pH} 7$ $\left(8.25 \mathrm{U} \mathrm{mL}^{-1}\right)$ and at $\mathrm{pH} 8\left(12.72 \mathrm{U} \mathrm{mL}^{-1}\right)$, respectively. This profile made these enzymes more suitable for bio-delipidation in near neutral $\mathrm{pH}$ conditions. Hence, the $\mathrm{pH}$ of the dissolved air floatation (DAF) pre-treated PSW are usually higher than $\mathrm{pH} 6$ [23]. A strain dependent characteristic was noted when the lipase enzymes produced by Bacillus cereus (B30) retained a higher activity over a broad range of $\mathrm{pH}$ conditions ( $\mathrm{pH} 4$ - 11). However, many lipases from Bacillus sp. were reported stable at alkaline conditions (pH 7 - 9) [19]. Generally, an optimum temperature facilitates enzyme-substrate binding, leading to high substrate conversion rates. For both isolates (Fig 3b), a decrease in activity was observed when the temperature was increased beyond $45{ }^{\circ} \mathrm{C}$, as opposed to other thermostable Bacillus sp., that can retain their activity at temperatures beyond $60^{\circ} \mathrm{C}[20]$.

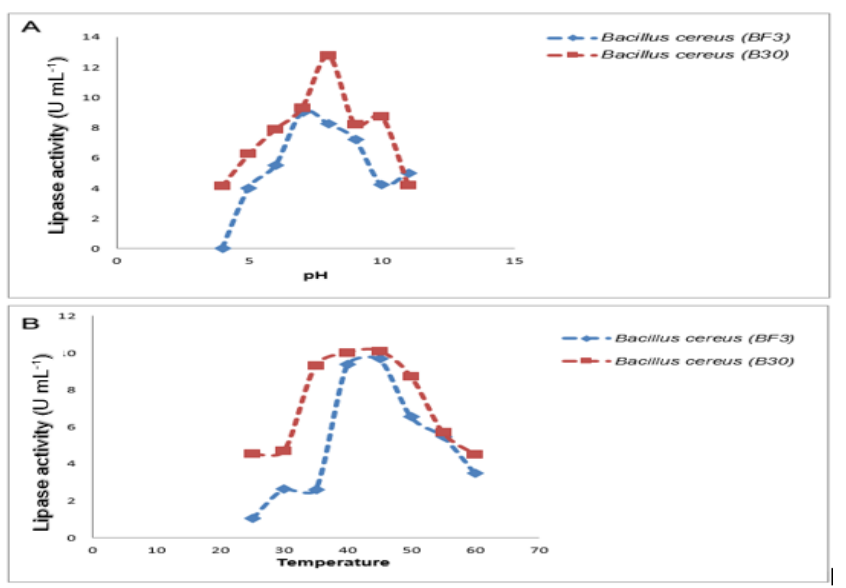

Fig. 3: The impact of $\mathrm{pH}(\mathrm{A})$ and temperature (B) on enzyme activity for Bacillus cereus ABI (BF3) and Bacillus cereus CC-1 (B30) strains.

\section{E. Effect of Solvents, Metal ions and Detergents on Enzyme Stability and Activity}

Table 1a shows the relative influence of metal ions and detergents on the enzyme activity of the isolates. $95.01 \%$ (BF3) and $89.94 \%$ (B30) lipases activity was retained in the presence of $\mathrm{Mg}^{2+}(1 \mathrm{mM})$ whereas more than $90 \%$ activity was lost in the $1 \mathrm{mM}$ EDTA, $\mathrm{Na}^{+}, \mathrm{Fe}^{2+}$, and $\mathrm{K}$ reaction mixtures. It was not suprising since most metal ions and detergents are known to negatively impact on activity and stability of lipases [21]. Detergents and metal ions are known to have an influence on the biological function of enzymes, by enhancing or inhibiting their activity via various mechanisms, such as acting as an electron donor or acceptor and forming complexes with limited reactivity [22]. Like any other enzyme, inhibition of lipase activity by these metal ions is caused by inhibition of the catalytic site [19].

TABLE I: EFFECT OF METAL IONS, DETERGENTS (A) AND ORGANIC SOLVENTS (B) ON LIPASE ACTIVITY OF BACILLUS CEREUS STRAINS AB1 (BF3) AND $C C$ - 1

\begin{tabular}{|c|c|c|c|}
\hline $\begin{array}{l}\text { Metal ion and } \\
\text { detergent } \\
\text { (A) }\end{array}$ & $\begin{array}{c}\text { Concentration } \\
(\mathbf{m M})\end{array}$ & $\begin{array}{c}\text { Relative } \\
\text { activity } \\
(\%) \\
\text { BF3 }\end{array}$ & $\begin{array}{c}\text { Relative } \\
\text { activity } \\
(\%) \\
\text { B3O }\end{array}$ \\
\hline Control & 0.0 & 100 & 100 \\
\hline $\mathrm{CaCl}_{2}$ & 1.0 & 9.41 & 11.95 \\
\hline $\mathrm{NaCl}$ & 1.0 & 3.70 & 8.83 \\
\hline $\mathrm{KCl}$ & 1.0 & 7.33 & 12.03 \\
\hline $\mathrm{MgSO}_{4}$ & 1.0 & 95.01 & 89.94 \\
\hline $\mathrm{FeSO}_{4}$ & 1.0 & 2.65 & 4.48 \\
\hline EDTA & 5.0 & 4.85 & 8.83 \\
\hline Triclosan & 1.0 & 81.36 & 73.91 \\
\hline Trichlorocarbonilide & 1.0 & 91.43 & 85.32 \\
\hline $\begin{array}{l}\text { Organic solvent } \\
\text { (B) }\end{array}$ & $\begin{array}{l}\text { Concentration } \\
(\% \mathrm{v} / \mathrm{v})\end{array}$ & $\begin{array}{l}\text { Relative } \\
\text { activity } \\
(\%) B F 3\end{array}$ & $\begin{array}{l}\text { Relative } \\
\text { activity } \\
(\%) B 3 O\end{array}$ \\
\hline Control & 0.0 & 100 & 100 \\
\hline 2-Mercaptoethanol & 30 & 25.4 & 23.49 \\
\hline Acetone & 30 & 15.56 & 26.72 \\
\hline Chloroform & 30 & 61.77 & 61.63 \\
\hline Ethanol & 30 & 71.20 & 71.05 \\
\hline Hexane & 30 & 79.90 & 77.68 \\
\hline Isopropanol & 30 & 85.14 & 85.97 \\
\hline Methanol & 30 & 84.47 & 83.78 \\
\hline Toulene & 30 & 88.70 & 90.00 \\
\hline
\end{tabular}

Inconsistently, activity of lipases from both strains was also considerably inhibited by $\mathrm{Ca}^{+}$, unlike lipases from numerous microorganisms, including those from Bacillus sp. that are $\mathrm{Ca}^{+}$ dependent. Considerable lipases activity was retained in reaction mixtures separately containing TCS $(81.36 \%$ and $73.91 \%$ for $B F 3$ and $B 30$, respectively) and TCC (91.43\% and $85.32 \%$ for $B F 3$ and $B 30$, respectively), which are often used as 
antimicrobial agents and disinfectants in slaughterhouses. In agreement, [23] observed more than $90 \%$ lipase retainment for C. aquatica BF-3 and Bacillus sp. BF-2 when TCS and TCC were also tested.

The presence of acetone and 2-Mercaptoethanol inhibited the lipase activity of both isolates by over $70 \%$ (Table $1 \mathrm{~b}$ ). In contrast, the enzymes from both isolates retained an activity of more than $60 \%$ in the presence of toulene, methanol, isopropanol, hexane, ethanol and chlorofom. It was interesting to realise that most organic solvents can support and maintain enzyme conformity that stimulates activity [24], [25].

\section{CONCLUSION}

Lipolytic microorganisms, Bacillus cereus AB1 (BF3) and $C C-1$ (B3O) were isolated from the PSW, identified using $16 \mathrm{~S}$ rRNA sequencing techniques and successfully screened for lipase activity. The interactive impact of environmental factors ( $\mathrm{pH}$ and temperature) on lipase production was revealed by RSM. Temperature, $\mathrm{pH}$, metal ions, detergents and organic solvents affected significantly on the lipase acivity and stability. Future works should focus on the applications of these lipolytic microorganisms in bio-delipidation systems.

\section{REFERENCES}

[1] A.R. Damásio, C.M.P. Braga, L.B. Brenelli, A.P. Citadini, F. Mandelli, J. Cota, R.F. De Almeida, V.H. Salvador, D.A.A. Paixao, F. Segato, and A.Z. Mercadante, "Biomass-to-bio-products application of feruloyl esterase from Aspergillus clavatus," Appl Microbiol Biotechnol., vol.97, no.15, pp. 6759-6767, August 2013. https://doi.org/10.1007/s00253-012-4548-4

[2] P.A. Faisal, E.S. Hareesh, P. Priji, K.N. Unni, S. Sajith, S. Sreedevi, M.S. Josh, and S. Benjamin, 'Optimization of parameters for the production of lipase from Pseudomonas sp. BUP6 by solid-state fermentation," $A d v$ Enzyme Res., vol. 2, no. 4, pp. 125-133, December 2014. https://doi.org/10.4236/aer.2014.24013

[3] V. Thakur, R. Tewari, and R. Sharma, "Evaluation of Production Parameters for Maximum Lipase Production by P. stutzeri MTCC 5618 and Scale-Up in Bioreactor," Chin J Biol, pp. 1-14, October 2014.

[4] M. Zarevúcka. (February 2012), "Olive oil as inductor of microbial lipase," In Olive Oil-Constituents, Quality, Health Properties and Bioconversions. InTech: pp. 458-470.

[5] S. Rani, and M. Kaur, 'Parameter optimization for lipase production by Bacillus megaterium using response surface methodology," "Indian $J$ Biochem Biophys., vol. 52, no. 1, pp. 311-315, October 2015.

[6] S. Cherif, S. Mnif, F. Hadrich, S. Abdelkafi, and S. Sayadi, 'A newly high alkaline lipase: an ideal choice for application in detergent formulations," Lipids Health Dis., vol. 10, no. 1, pp. 221-229, November 2011.

https://doi.org/10.1186/1476-511X-10-221

[7] C.F. Bustillo-Lecompte, and M. Mehrvar, "Treatment of actual slaughterhouse wastewater by combined anaerobic-aerobic processes for biogas generation and removal of organics and nutrients: An optimization study towards a cleaner production in the meat processing industry," $J$ Clean Prod., vol. 141, no. 1, pp. 287-302, January 2017. https://doi.org/10.1016/j.jclepro.2016.09.060

[8] L. Ramnath, B. Sithole, and R. Govinden, 'Identification of lipolytic enzymes isolated from bacteria indigenous to Eucalyptus wood species for application in the pulping industry," Biotechnol Rep., vol. 15, no. 1, pp. 114-124, July 2017. https://doi.org/10.1016/j.btre.2017.07.004

[9] M.M. Bradford, "A rapid and sensitive method for the quantitation of microgram quantities of protein utilizing the principle of protein-dye binding,"' Anal. Biochem., vol. 72, no. 1-2, pp. 248-254, May 1976. https://doi.org/10.1016/0003-2697(76)90527-3

[10] K.S. Jaiswal, and V.K. Rathod, "Acoustic cavitation promoted lipase catalysed synthesis of isobutyl propionate in solvent free system:
Optimization and kinetic studies," Ultrason Sonochem., vol. 40, no, 1, pp. 27-735, January 2018.

https://doi.org/10.1016/j.ultsonch.2017.07.026

[11] P. Pallavi, P. Bhavani, J. Komali, and T. Manjusha, "Molecular Identification of Lipase Producing Bacteria based on 16S rDNA Sequencing," Curr Microbiol., vol, 6, no. 5, pp. 2067-2071, May 2017.

[12] N. Venkateshwarlu, and S.M. Reddy, "Production of lipase by five thermophilic fungi," Indian J Microbiol., vol. 33, no. 2, pp. 119-124, June 1993.

[13] J. Wongwatanapaiboon, W. Malilas, C. Ruangchai, G. Thummadetsak, S. Chulalaksananukul, A. Marty, and W. Chulalaksananukal, "Overexpression of Fusarium Solani lipase in Pichiapastori and its application in lipid degradation," J. Agric. Environ. Biotechnol., vol. 30, no. 5, pp. 885-893, June 2016.

[14] M. Esteban-Torres, J.M. Mancheño, B. de las Rivas, and R. Munoz, "Characterization of a halotolerant lipase from the lactic acid bacteria Lactobacillus plantarum useful in food fermentations," LWT-Food Sci Technol., vol. 60, no. 1, pp. 246-252, January 2015. https://doi.org/10.1016/j.lwt.2014.05.063

[15] S. Gupta, P. Ingole, K. Singh, and A. Bhattacharya, "Comparative study of the hydrolysis of different oils by lipase-immobilized membranes,"' $J$ Appl Polym Sci., vol. 124, no. 1, pp. 17-26, November 2012. https://doi.org/10.1002/app.35400

[16] F. Pabai, S. Kermasha, and A. Morin, "Use of continuous culture to screen for lipase-producing microorganisms and interesterification of butter fat by lipase isolates," Can J Microbiol., vol. 42, no. 5, pp. 446-452, May 1996. https://doi.org/10.1139/m96-061

[17] H. Dong, S. Gao, S.P. Han, and S.G. Cao, 'Purification and characterization of a Pseudomonas sp. lipase and its properties in non- aqueous media", Appl Biochem Biotechnol, vol. 30, no. 3, pp. 251-256, December 1999.

[18] C.H. Ali, A.S. Qureshi, S.M. Mbadinga, J.F. Liu, S.Z. Yang, and B.Z. $\mathrm{Mu}$, 'Biodiesel production from waste cooking oil using onsite produced purified lipase from Pseudomonas aeruginosa FW_SH-1: Central composite design approach," Renew Energy., 109(1):93-100, August 2017. https://doi.org/10.1016/j.renene.2017.03.018

[19] S. Dutta, and L. Ray, "Production and characterization of an alkaline thermostable crude lipase from an isolated strain of Bacillus cereus C7,", Appl Biochem Biotechnol., vol. 159, no. 1, pp. 142-154, October 2009. https://doi.org/10.1007/s12010-009-8543-x

[20] D. Sharma, B. Sharma, and A. Shukla,. "Biotechnological approach of microbial lipase: a review," Biotechnol., vol. 10, no. 1, pp. 23-40, 2011. https://doi.org/10.3923/biotech.2011.23.40

[21] D.K. Kanderi, U. Yadav, S.V. Satyanarayana, and S, Verma, "Characterization of partially purified lipase from Saccharomyces cerevisiae," Int J Pharm Sci Res., vol. 6, no. 8, pp. 514-517, August 2014.

[22] S. Sachan, V. Chandra,., A. Yadu, and A. Singh, "Cobalt has Enhancing Effect on Extracellular Lipases Isolated from Pseudomonas aeroginosa JCM5962 (T)," Int.J. PharmTech Res., vol. 10, no. 1, pp. 45-49, May 2017. https://doi.org/10.20902/IJPTR.2017.1016

[23] C. Dlangamandla, S. K. O. Ntwampe, and M. Basitere, "A bioflocculant-supported dissolved air flotation system for the removal of suspended solids, lipids and protein matter from poultry slaughterhouse wastewater," Wat Sci Tech., vol. 78, no. 2, pp. 452-458, August 2018. https://doi.org/10.2166/wst.2018.324

[24] P.S. Borkar, R.G. Bodade, S.R. Rao, and C.N. Khobragade, 'Purification and characterization of extracellular lipase from a new strain: Pseudomonas aeruginosa SRT 9,' Braz J Microbiol., vol. 40, no. 2, pp. 358-366, April 2009. https://doi.org/10.1590/S1517-83822009000200028

[25] R. Tripathi, J. Singh, R.K. Bharti, and I.S. Thakur, 'Isolation, purification and characterization of lipase from Microbacterium sp. and its application in biodiesel production," Energy Procedia., vol. 54, no. 1, pp. 518-529, December 2014.

https://doi.org/10.1016/j.egypro.2014.07.293 


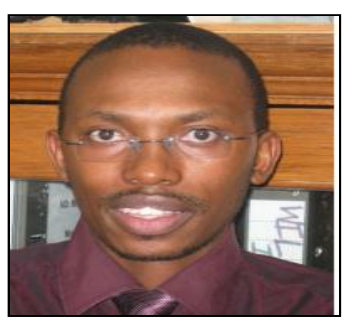

S.K.O Ntwampe is the chair and head of the Department of Biotechnology and Consumer Sciences at Cape Peninsula University of Technology. He is also the head of Bioresource Engineering Research Group $(B i o E R G)$ in the Faculty of Applied Sciences.

His recently publications are :

https://doi.org/10.1016/j.dib.2018.01.017

https://doi.org/10.4491/eer.2017.154

https://doi.org/10.1007/s10661-018-6634-2

https://doi.org/10.3390/w10050591 